\title{
PLK2 wt Allele
}

National Cancer Institute

\section{Source}

National Cancer Institute. PLK2 wt Allele. NCI Thesaurus. Code C51320.

Human PLK2 wild-type allele is located within $5 q 12.1-q 13.2$ and is approximately $6 \mathrm{~kb}$ in length. This allele, which encodes serine/threonine-protein kinase PLK2 protein, plays a role in cell cycle regulation. PLK2 gene expression is transcriptionally down-regulated in Bcell neoplasms. 